\title{
PENINGKATAN AKTIVITAS DAN HASIL BELAJAR MATEMATIKA MELALUI MODEL PEMBELAJARAN MAKE A MATCH BERBANTUAN KARTU ANGKA
}

\section{Tri Winarni ${ }^{凶}$}

SD 4 Karangmalang Gebog Kudus

\begin{tabular}{|c|c|}
\hline Info Artikel & Abstract \\
\hline $\begin{array}{l}\text { Sejarah Artikel: } \\
\text { Diterima } 1 \text { Okt } 2019 \\
\text { Direvisi } 2 \text { Nov } 2019 \\
\text { Disetujui } 6 \text { Nov } 2019 \\
\\
\text { Keywords: } \\
\text { Make a Match, Card } \\
\text { Number. } \\
\text { Papertype: } \\
\text { Research paper }\end{array}$ & $\begin{array}{l}\text { This research is to increase the activity and learning outcomes of mathematics about numbers through } \\
\text { the application of the make a match learning model assisted by the number card media. Classroom } \\
\text { action research was conducted on grade } 1 \text { students of SD } 4 \text { Karangmalang, Gebog, Kudus of the } \\
\text { Academic Year } 2017 / 2018 \text { with } 13 \text { students consisting of } 8 \text { male students and } 5 \text { female students. The } \\
\text { method used is classroom action research consisting of } 2 \text { cycles, each cycle consisting of } 4 \text { stages, } \\
\text { namely planning, implementation, observation, and reflection. In cycles } 1 \text { and } 2 \text { the actions taken with } \\
\text { make a match learning model are assisted by number card media. There are the results of the } \\
\text { research:: (1) Mathematical learning activities about numbers increased after being taught with a } \\
\text { make a match learning model assisted by number card media. Increased student learning activities by } \\
9,81 \text {, from the initial condition of } 69,81 \text { to 79,62 in the final condition; (2) The results of learning } \\
\text { mathematics about numbers increases after being taught with the make a match learning model } \\
\text { helped by the media card numbers. Increased student learning outcomes by 17,68 from the initial } \\
\text { condition of } 65,38 \text { to 83,08 in the final condition. }\end{array}$ \\
\hline
\end{tabular}

\begin{abstract}
Abstrak
Penelitian ini adalah untuk meningkatkan aktivitas dan hasil belajar matematika tentang bilangan melalui penerapan model pembelajaran make a match berbantuan media kartu angka. Penelitian tindakan kelas dilakukan pada siswa kelas I SD 4 Karangmalang, Gebog, Kudus Semester 1 Tahun Pelajaran 2017/2018 dengan jumlah siswa 13 terdiri dari 8 siswa laki-laki dan 5 siswa perempuan. Metode yang digunakan adalah penelitian tindakan kelas yang terdiri dari 2 siklus, masing-masing siklus terdiri dari 4 tahapan yaitu perencanaan, pelaksanaan, pengamatan, dan refleksi. Pada siklus 1 dan 2 tindakan yang dilakukan dengan model pembelajaran make a match berbantuan media kartu angka. Hasil penelitian menunjukkan hasil sebagai berikut: (1) Aktivitas belajar matematika tentang bilangan meningkat setelah dibelajarkan dengan model pembelajaran make a match berbantuan media kartu angka. Peningkatan aktivitas belajar siswa sebesar 9,81, dari kondisi awal 69,81 menjadi 79,62 pada kondisi akhir; (2) Hasil belajar matematika tentang bilangan meningkat setelah dibelajarkan dengan model pembelajaran make a match berbantuan media kartu angka. Peningkatan hasil belajar siswa sebesar 17,68 dari kondisi awal 65,38 menjadi 83,08 pada kondisi akhir.
\end{abstract}

(C) 2019 Universitas Muria Kudus

\footnotetext{
Alamat korespondensi:

Program Studi Pendidikan Matematika

Fakultas Keguruan dan Ilmu Pendidikan Universitas Muria Kudus

Kampus UMK Gondangmanis, Bae Kudus Gd. L. 1t I PO. BOX 53 Kudus

Tlp (0291) 438229 ex.147 Fax. (0291) 437198

E-mail: winarnitri839@gmail.com
} p-ISSN 2615-4196 


\section{PENDAHULUAN}

Matematika sangat penting dalam kehidupan sehari-hari, karena dalam setiap aspek kehidupan tidak akan lepas dari matematika. Berbagai bentuk simbol, rumus, teorema, dalil, ketetapan, serta konsep digunakan untuk membantu perhitungan, pengukuran, penilaian, peramalan, dan lain-lain. Sehingga belajar matematika memerlukan cara-cara khusus dalam belajar dan mengajarkannya. Namun pada kenyataannya pada kondisi awal saat peneliti memulai penelitian ini, hasil belajar siswa tentang bilangan rendah. Yang ditunjukkan dengan rata-rata kelas hanya mencapai 65,38 di bawah KKM matematika 70.

Salah satu upaya mengatasi masalah tersebut perlu dilakukan pendekatan-pendekatan tertentu untuk memudahkan siswa dalam belajar. Misalnya, melaksanakan tanggung jawab individunya sebagai anggota kelompok dan atau mengurangi kebosanan atau kejenuhan jika guru mengelompokkan siswa secara permanen. Termasuk mengarahkan kegiatan siswa yang dimulai dengan mencari dan menemukan isi materi pembelajaran. Salah satu upaya yang dapat dilakukan untuk meningkatkan aktivitas dan hasil belajar matematika ini peneliti menerapkan model pembelajaran make a match.

Model pembelajaran make a match adalah strategi yang cukup menyenangkan yang digunakan untuk mengulang materi yang telah diberikan sebelumnya. Namun, materi baru juga tetap bisa disampaikan melalui model ini. Sebelumnya siswa diberikan tugas untuk mempelajari topik yang akan diajarkan terlebih dahulu.

Sintaks atau langkah-langkah model pembelajaran make a match adalah sebagai berikut (Huda, 2013:252): (1) Guru menyampaikan materi dan memberikan tugas kepada siswa untuk dipelajari di rumah, (2) Siswa dibagi ke dalam dua kelompok yaitu kelompok A dan B kedua kelompok diminta untuk saling berhadapan, (3) Langkah selanjutnya yaitu guru membagikan kartu pertanyaan kepada kelompok A dan kartu jawaban kepada kelompok B, (4) Guru menyuruh siswa untuk mencocokkan kartu yang sudah dipegang kepada teman yang lain. Sebelum permainan mencari pasangan dilakukan, guru terlebih dahulu meyampaikan batasan waktu yang diberikan, (5) Guru meminta siswa untuk mencari pasangannya. Bagi siswa yang sudah menemukan pasangan kartu, maka wajib untuk melaporkan dirinya kepada guru, (6) Jika waktu yang diberikan sudah habis, guru akan memberitahukan kepada siswa bahwa waktu permainan sudah habis. Siswa yang tidak bisa menemukan pasangannya diminta untuk berkumpul tersendiri, (7) Guru memanggil siswa untuk mempresentasikan hasil pekerjaannya. Teman yang lain memberikan tanggapan apakah pasangan kartu itu cocok atau tidak, (8) Pada langkah terakhir guru memberikan konfirmasi tentang kebenaran dan kecocokan pertanyaan dan jawaban yang telah dikerjakan siswa, (9) Guru memanggil kelompok yang lain, begitu seterusnya sampai seluruh pasangan melakukan presentasi.

Keunggulan dari model pembelajaran make a match sebagai berikut (Huda, 2013:253): (1) Dapat meningkatkan aktivitas belajar siswa baik secara kognitif maupun fisik, (2) Model ini akan membuat siswa merasa senang karena terdapat unsur permainan, (3) Meningkatkan motivasi siswa dalam mempelajari materi pelajaran, (4) Melatih keberanian siswa untuk tampil menyampaikan presentasi di depan kelas, (5) Efektif melatih kedisiplinan siswa menggunakan waktu untuk belajar.

Sedangkan kelemahan menggunakan model pembelajaran make a match adalah: (1) Membutuhkan waktu yang banyak, (2) Pada awal penerapan model, terapat siswa yang masih malumalu dengan pasangannya, (3) Jika guru tidak mengarahkan dengan baik, akan banyak siswa yang kurang memperhatikan pada saat presentasi, (4) Guru harus berhati-hati dan bersikap bijak ketika memberikan hukuman kepada siswa yang tidak mendapat pasangan, (5) Menggunakan model ini secara terus menerus dapat menimbulkan kebosanan.

Alasan peneliti memilih model pembelajaran tersebut karena dengan model pembelajaran kooperatif tipe make a match ini dapat meningkatkan interaksi aktivitas antara guru dengan siswa dan siswa dengan siswa pada diskusi kelompok, dapat membuat siswa aktif mengikuti pembelajaran, meningkatkan daya kreativitas siswa dengan mencari pasangan kartu, melatih rasa percaya diri siswa pada saat presentasi hasil diskusi, dan menambah aktivitas siswa dalam belajar matematika.

Pada model pembelajaran ini terdapat permainan kartu untuk mencari pasangan yang dapat menarik perhatian siswa selama proses pembelajaran. Hal ini sesuai dengan karakter siswa kelas I yang suka bermain.

Untuk melengkapi model pembelajaran make a match peneliti menggunakan media kartu angka. Media kartu angka ini merupakan media visual yang dapat memperlancar pemahaman dan memperkuat ingatan. Visualisasi dapat pula menumbuhkan minat siswa dan dapat memberikan hubungan antara isi materi pelajaran dengan dunia nyata. 
Kartu angka merupakan media visual diam yang tidak diproyeksikan. "Berbagai media yang tidak diproyeksikan seperti gambar, poster, chart, realia atau lainnya yang akan digunakan dalam proses pembelajaran kadang kala membutuhkan tempat untuk mendisplay atau memajang" (Uno, 2011:131).

Penggunaan media kartu angka dalam pembelajaran memiliki kelebihan (Ginnis, 2008:157): (1) kegiatan ini berbeda dan menyenangkan, oleh karenanya materi lebih mudah diingat, (2) ini menuntut siswa berpikir, mengingat, memprediksi, menghitung. dengan kegiatan ini menuntut semua orang untuk terlibat, ini membantu siswa untuk berpikir secara terbuka, (3) dilevel lebih lanjut, membuat perbedaan lebih kecil, memperkuat kebutuhan untuk belajar, dapat menjawab pertanyaan dengan lebih tepat

Model pembelajaran make a match yang mempunyai tujuan pendalaman materi, menggali materi, sekaligus untuk selingan. Pendalaman materi dengan cara memasangkan antara pertanyaan dan jawaban. Jika digunakan untuk menggali materi kita menuliskan pokok-pokok materi. Apalagi disertai dengan kartu gambar yang menarik dan mempermudah siswa dalam membaca dan menulisnya maka kegiatan ini diharapkan dapat meningkatkan aktivitas dan hasil belajar matematika.

Berdasarkan identifikasi masalah di atas maka rumusan masalah dalam penelitian ini adalah: (1) Bagaimana peningkatan aktivitas belajar matematika tentang bilangan pada siswa kelas I SD 4 Karangmalang Kecamatan Gebog Kabupaten Kudus Semester I Tahun Pelajaran 2017/2018 setelah dibelajarkan dengan model pembelajaran make a match berbantuan media kartu angka?, (2) Bagaimana peningkatan hasil belajar matematika tentang bilangan pada siswa kelas I SD 4?

Karangmalang Kecamatan Gebog Kabupaten Kudus Semester I Tahun Pelajaran 2017/2018 setelah dibelajarkan dengan model pembelajaran make a match berbantuan media kartu angka?

Adapun indikator aktivitas belajar yang dikaji dalam penelitian ini adalah: (a) keantusiasan siswa untuk mengikuti pembelajaran, (b) ketertiban siswa dalam pembelajaran, (c) ketepatan memasangkan kartu, (d) partisipasi siswa dalam menyimpulkan materi

Tujuan penelitian ini untuk: (1) Peningkatan aktivitas belajar matematika tentang bilangan pada, (2) Peningkatan hasil belajar matematika tentang bilangan dengan model pembelajaran make a match berbantuan media kartu angka.
Penelitian tindakan kelas ini diharapkan dapat memberikan manfaat bagi: (1) Bagi Siswa; (a) dapat meningkatkan aktivitas belajar matematika tentang bilangan, (b) dapat meningkatkan hasil belajar matematika tentang bilangan; (2) Bagi Peneliti: (a) melalui model pembelajaran make a match berbantuan media kartu angka dapat meningkatkan aktivitas belajar matematika tentang bilangan pada siswa kelas I SD 4 Karangmalang Kecamatan Gebog Kabupaten Kudus Semester I Tahun Pelajaran 2017/2018, (b) melalui model pembelajaran make a match berbantuan media kartu angka dapat meningkatkan hasil belajar matematika tentang bilangan pada siswa kelas I SD 4 Karangmalang Kecamatan Gebog Kabupaten Kudus Semester I Tahun Pelajaran 2017/2018; (3) Bagi Sekolah: (a) hasil penelitian ini dapat menambah sekaligus melengkapi hasil-hasil penelitian yang telah dilakukan guru-guru lain, (b) memberikan kontribusi pada sekolah dalam rangka perbaikan proses pembelajaran matematika sehingga dapat meningkatkan hasil belajar siswa.

\section{METODE PENELITIAN}

Penelitian Tindakan Kelas ini peneliti mulai pada bulan Juli 2017 sampai Oktober 2017. Langkah awal peneliti mempersiapkan proposal dan instrumen penelitian pada bulan Juli 2017. Dilanjutkan pelaksanaan pembelajaran siklus I dan siklus II pada bulan Agustus 2016. Peneliti mulai menyusun laporan di bulan September dan Oktober 2017.

Penelitian Tindakan Kelas ini peneliti laksanakan di kelas I SD 4 Karangmalang Kecamatan Gebog Kabupaten Kudus tahun pelajaran 2017/2018.

Penelitian Tindakan Kelas ini subjek penelitianya siswa kelas I SD 4 Karangmalang Kecamatan Gebog tahun pelajaran 2017/2018 yang berjumlah 13 siswa terdiri dari 8 siswa putra dan 5 siswa putri. Penelitian Tindakan Kelas ini objeknya adalah Mata pelajaran matematika tentang bilangan.

Bentuk data yang diambil yaitu data kuantitatif dan kualitatif. Data hasil belajar matematika merupakan data kuantitatif. Data aktivitas belajar matematika adalah data kualitatif. Banyaknya data ada 6 yaitu (1) jurnal refleksi kondisi awal; (2) data hasil belajar matematika kondisi awal; (3) data aktivitas belajar siklus I; (4) data hasil belajar matematika pada siklus 1; (5) data aktivitas belajar matematika siklus II (6) data hasil belajar pada siklus 2. Data kondisi awal tentang hasil belajar matematika ada di daftar nilai. Sumber data Penelitian Tindakan Kelas dari siswa kelas I SD 4 Karangmalang Kecamatan Gebog 
tahun pelajaran 2017/2018 yang berjumlah 13 siswa terdiri dari 8 siswa putra dan 5 siswa putri sebagai sumber utama penelitian tindakan kelas.

Teknik pengumpulan data: (1) Teknik dokumentasi berupa jurnal refleksi pembelajaran digunakan untuk mencari data kondisi awal aktivitas belajar matematika dan hasil belajar matematika. Dokumentasi aktivitas belajar matematika dapat dilihat jurnal mengajar guru, (2) Teknik pengamatan atau observasi digunakan untuk memperoleh data aktivitas belajar matematika siswa pada siklus 1 dan 2. Pengamatan dan observasi dilakukan oleh teman sejawat selaku kolaborator yang bertugas mengamati aktivitas siswa dan aktivitas guru dengan memberikan check list pada lembar observasi, (3) Teknik tes tertulis digunakan untuk memperoleh data hasil belajar matematika pada siklus 1 dan 2 yang dilaksanakan pada tiap akhir siklus.

Alat pengumpulan data: (1) Dokumen daftar nilai untuk data hasil belajar matematika pada kondisi awal, (2) Dokumen catatan personal siswa dan jurnal mengajar guru untuk data aktivitas belajar matematika siswa kondisi awal, (3) Lembar observasi/pengamatan untuk mencari data aktivitas belajar matematika siswa pada siklus 1, (4) Butir soal tes tertulis untuk hasil belajar matematika pada siklus 1, (5) Lembar observasi/pengamatan untuk mencari data aktivitas belajar matematika pada siklus 2, (6) Butir soal tes tertulis untuk hasil belajar matematika pada siklus 2 .

Validasi dilakukan untuk memperoleh data yang valid. Validasi data diperoleh melalui teknik: (1) Data aktivitas belajar matematika diperoleh melalui teknik observasi/pengamatan untuk memperoleh data yang valid divalidasi dengan bantuan kolaborasi dengan teman sejawat (triangulasi sumber antara peneliti, teman sejawat selaku kolaborator dan siswa), (2) Data hasil belajar matematika diperoleh melalui teknik tes tertulis alatnya berupa butir soal tes tertulis supaya valid perlu dibuat kisi-kisi sebelum soal disusun. Validasi dilakukan terhadap instrumen penilaian tes tertulis berupa penyusunan kisi-kisi sehingga terpenuhi validitas teoretik, khususnya content validity.

Analisis data: (1) Teknik kualitatif. Dianalisis menggunakan teknik deskriptif komparatif dilanjutkan dengan refleksi. Data aktivitas belajar siswa kondisi awal, siklus 1, dan siklus 2, (2) Teknik Kuantitatif dari data hasil belajar matematika tentang bilangan yang diambil dari kondisi awal, siklus 1, siklus 2. Data kondisi awal di daftar nilai.

Indikator kinerja: (1) Indikator keberhasilan direfleksikan dengan siswa memperoleh nilai rata-rata aktivitas belajar skor $\geq 75$, (2) Indikator keberhasilan direfleksikan dengan siswa memperoleh nilai rata-rata hasil belajar matematika $\geq 70$.

Prosedur penelitian menggunakan Metode Penelitian Tindakan Kelas. Penelitian ini dilaksanakan sebanyak dua siklus dan tiap siklus terdiri dari 2 pertemuan, tiap pertemuan yang melalui 4 tahap yaitu: (1) perencanaan, (2) Pelaksanaan, (3) Pengamatan, (4) Refleksi

\section{HASIL DAN PEMBAHASAN}

\section{Aktivitas Belajar Siswa}

Berikut perbandingan aktivitas belajar kondisi awal dan kondisi akhir:

Tabel 1 Perbandingan Aktivitas Belajar Kondisi Awal dan Akhir

\begin{tabular}{lll}
\hline Uraian & $\begin{array}{l}\text { Kondisi } \\
\text { Awal }\end{array}$ & $\begin{array}{l}\text { Kondisi } \\
\text { Akhir }\end{array}$ \\
\hline Aktivitas & 69,81 & 79,62 \\
Belajar & & \\
Siswa & & \\
\hline
\end{tabular}

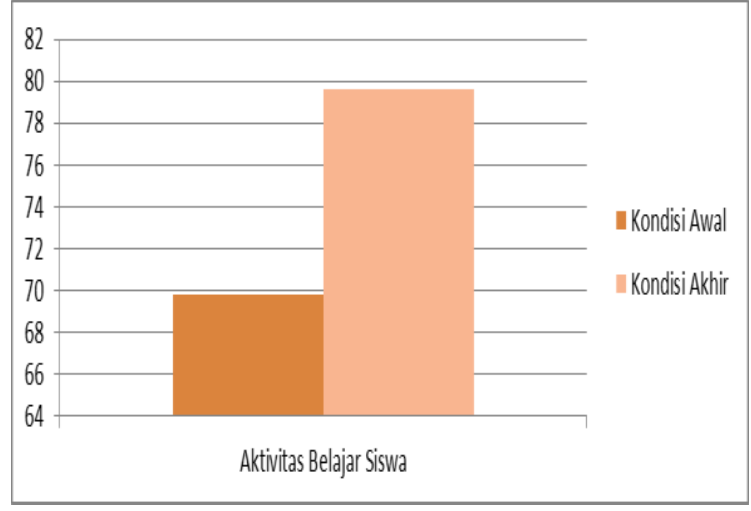

Gambar 1 Perbandingan Aktivitas Belajar Kondisi Awal, Akhir

Diketahui aktivitas belajar siswa terjadi peningkatan skor sebesar 13,56 dari kondisi awal 63,94 pada kondisi akhir mencapai 77,5. Hal ini membuktikan bahwa dengan model pembelajaran make a match berbantuan media kartu angka dapat meningkatkan aktivitas belajar siswa.

Aspek-aspek aktivitas belajar siswa penelitian tindakan kelas ini meliputi: (1) Keantusiasan siswa untuk mengikuti pembelajaran, (2) Ketertiban siswa dalam pembelajaran, (3) Ketepatan memasangkan kartu, (4) Partisipasi siswa dalam menyimpulkan materi.

Peneliti menerapkan model pembelajaran make a match berbantuan media kartu angka pada siklus I dan II untuk meningkatkan aktivitas 
belajar siswa dalam pembelajaran matematika tentang bilangan.

Dengan langkah tersebut diketahui peningkatan aktivitas belajar siswa meningkat sebesar 9,81 dari kondisi awal 69,81 pada kondisi akhir mencapai 79,62. Hal ini membuktikan bahwa dengan model pembelajaran make a match berbantuan media kartu angka dapat meningkatkan aktivitas belajar matematika tentang bilangan bagi siswa kelas I SD 4 Karangmalang semester I Tahun 2017/2018.

\section{Hasil Belajar Siswa}

Berikut perbandingan hasil belajar kondisi awal dengan kondisi akhir seperti berikut:

Tabel 2 Perbandingan Hasil Belajar Kondisi Awal, Akhir

\begin{tabular}{lll}
\hline Keterangan & Kondisi Awal & $\begin{array}{l}\text { Kondisi } \\
\text { Akhir }\end{array}$ \\
\hline Rata-rata & 65,38 & 83,08 \\
Siswa & 6 & 13 \\
Tuntas & & \\
Siswa & 7 & 0 \\
Belum & & \\
Tuntas & & \\
& & \\
\hline
\end{tabular}

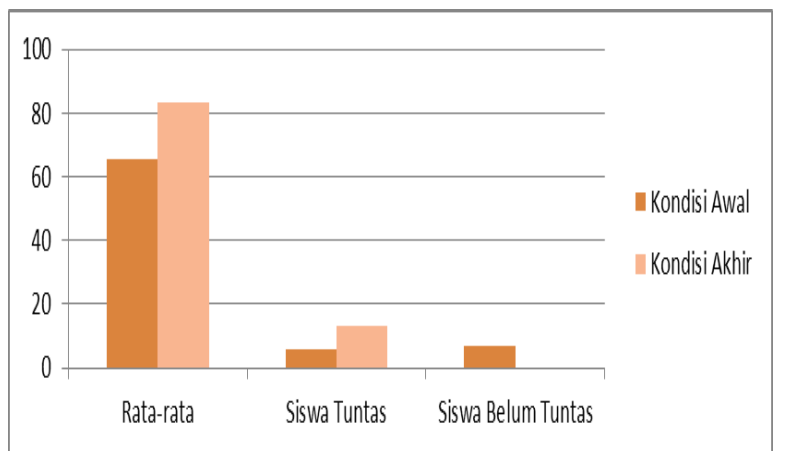

Gambar 2 Perbandingan Hasil Belajar Kondisi Awal, Akhir

Hasil belajar siswa yang meningkat 17,68 ditunjukkan dengan rata-rata siswa kondisi awal 65,38 kondisi akhir mencapai 83,08. Dalam pembelajaran matematika tentang bilangan peneliti menggunakan model pembelajaran make a match berbantuan media kartu angka. Target penelitian sudah tercapai sehingga penelitian dihentikan pada siklus II. Hal ini membuktikan bahwa pada kondisi akhir aktivitas dan hasil belajar siswa dapat ditingkatkan dan telah mencapai target penelitian setelah dibelajarkan dengan model pembelajaran make a match berbantuan media kartu angka.

Setelah dibelajarkan dengan model pembelajaran make a match berbantuan media kartu angka hasil belajar matematika tentang bilangan bagi siswa kelas I SD 4 Karangmalang semester I Tahun 2017/2018 dapat ditingkatkan. Hasil belajar siswa yang meningkat 9,81 ditunjukkan dengan rata-rata siswa kondisi awal 69,81 kondisi akhir mencapai 79,62.

Peningkatan hasil belajar dikarenakan penerapan model pembelajaran make a match berbantuan media kartu angka pada pembelajaran matematika tentang bilangan. Hal ini membuktikan bahwa model pembelajaran make a match berbantuan media kartu angka dapat meningkatkan aktivitas dan hasil belajar matematika tentang bilangan bagi siswa kelas I SD 4 Karangmalang semester I Tahun 2017/2018.

Sesuai dengan pendapat Huda (2013:253) keunggulan dari model pembelajaran make a match sebagai berikut: (1) Dapat meningkatkan aktivitas belajar siswa baik secara kognitif maupun fisik, (2) Model ini akan membuat siswa merasa senang karena terdapat unsur permainan, (3) Meningkatkan motivasi siswa dalam mempelajari materi pelajaran, (4) Melatih keberanian siswa untuk tampil menyampaikan presentasi di depan kelas, (5) Efektif melatih kedisiplinan siswa menggunakan waktu untuk belajar.

Selain itu aktivitas dan hasil belajar matematika tentang bilangan bagi siswa kelas I SD 4 Karangmalang semester I Tahun 2017/2018 dapat ditingkatkan dengan media gambar.

Hal ini sesuai dengan pendapat Ginnis (2008:157) penggunaan media kartu angka dalam pembelajaran memiliki kelebihan: (1) Kegiatan ini berbeda dan menyenangkan, oleh karenanya materi lebih mudah diingat, (2) Ini menuntut siswa berpikir, mengingat, memprediksi, menghitung. Dengan kegiatan ini menuntut semua orang untuk terlibat, ini membantu siswa untuk berpikir secara terbuka, (3) Dilevel lebih lanjut, membuat perbedaan lebih kecil, memperkuat kebutuhan untuk belajar, dapat menjawab pertanyaan dengan lebih tepat.

\section{SIMPULAN}

Berdasarkan hasil penelitian dan pembahasan yang telah diuraikan, maka dapat diambil simpulan bahwa penerapan model pembelajaran make a match berbantuan media kartu angka dapat meningkatkan aktivitas dan hasil belajar matematika tentang bilangan pada siswa kelas I SD 4 Karangmalang semester I Tahun 2017/2018.

Berdasarkan hasil analisis disimpulkan halhal berikut; (1) Aktivitas belajar matematika tentang bilangan meningkat setelah dibelajarkan dengan model pembelajaran make a match 
berbantuan media kartu angka. Peningkatan aktivitas belajar siswa sebesar 9,81, dari kondisi awal 69,81 menjadi 79,62 pada kondisi akhir, (2) Hasil belajar matematika tentang bilangan meningkat setelah dibelajarkan dengan model pembelajaran make a match berbantuan media kartu angka. Peningkatan hasil belajar siswa sebesar 17,68 dari kondisi awal 65,38 menjadi 83,08 pada kondisi akhir.

\section{DAFTAR PUSTAKA}

Ginnis, P. 2008. Trik dan Taktik Mengajar (Strategi Meningkatkan Pencapaian Pengajaran di Kelas). Jakarta. PT. Indeks

Huda, Miftahul. 2013. Model-Model Pengajaran dan Pembelajaran. Yogyakarta: Pustaka Pelajar.
Slameto. 2013. Belajar Dan Faktor-Faktor Yang Mempengaruhinya. Jakarta: Rineka Cipta.

Sudjana, Nana. 2012. Penilaian Proses hasil belajar mengajar. Bandung: Remaja Rosdakarya.

Uno, H; Mohamad, N. 2011. Belajar dengan Pendekatan PAIKEM. Jakarta: PT Bumi Aksara.

Uzer, Usman, Moh. 2013. Menjadi Guru Profesional. Bandung:PT. Remaja Rosdakarya.

Wijaya, A. 2012. Pendidikan Matematika Realistik Suatu Alternatif Pendekatan Pembelajaran

Matematika. Yogyakarta: Grah 